Abstract\#: A-2021-RE10014

Tao Xingzhi Study Association of China \& Huzhou University

May 28-30, 2021, Huzhou, Zhejiang Province, China

\title{
Personal Experienced: An Exploration of Better Life Education Based on Goal Orientation
}

\section{Fengmei Cao}

Affiliation: Hangzhou Xingchen Kindergarten, Hangzhou 310000, Zhejiang, China

Address: Hangzhou Xingchen Kindergarten, Hangzhou 310000, Zhejiang, China.

Correspondence to: Fengmei Cao, E-mail:285852362@qq.com

DOI: https://doi.org/10.15354/sief.21.s1.ab041

The authors declare no competing interest.

Mr. Xingzhi Tao once presented that the life we are experiencing is the education we received. To live a healthy life is to get a healthy education and to live a scientific life is to get a scientific education. The core concept is to experience education personally through life experiences. As mentioned in the Guide that children's learning ability should be improved through personal experience, direct perception, and practical exploration, which shows the importance of personal experience in life education. On the basis of goal-oriented exploration, this article conducted a research on children's personal life and education experiences, which focusing on children's real needs, considering the learners, establishing reasonable expectations of children's development, providing various development opportunities in life. And then support children to experience, perceive, manipulate, express, and perform, so as to promote them to make progress in reflections throughout the practical experience.

Keywords

GoodLife, Life Education, Goal-Oriented, Experiencing Growth, Reflection

Science Insights Education Frontiers, 2021 September 13; Vol. 10, Suppl. 1, pp.11.

(C) 2021 Insights Publisher. All rights reserved.

(c) (i) Creative Commons Non Commercial CC BY-NC: This article is distributed under the terms of the Creative Commons Attribution-NonCommercial 4.0 License which permits non-commercial use, reproduction and distribution of the work without further permission provided the original work is attributed by the Insights Publisher. 